\title{
Nutritional composition of the branched murex Chicoreus ramosus (Linnaeus, 1758) (Family: Muricidae)
}

\author{
SOUMYA SALAS ${ }^{1,3}$, KAJAL CHAKRABORTY $^{1}$, P. T. SARADA ${ }^{2}$ AND P. VIJAYAGOPAL ${ }^{1}$ \\ ${ }^{1}$ ICAR-Central Marine Fisheries Research Institute, Ernakulam North P.O., Kochi - 682 018, Kerala, India \\ ${ }^{2}$ Madras Research Centre of ICAR-Central Marine Fisheries Research Institute, Santhome High Road, RA Puram \\ Chennai - 600 028, Tamil Nadu, India \\ ${ }^{3}$ Mangalore University, Mangalagangothri - 574 199, Karnataka, India \\ e-mail:kajal_cmfri@yahoo.com,kajal.chakraborty@icar.gov.in
}

\begin{abstract}
Chicoreus ramosus (Linnaeus, 1758), the branched murex, a species of marine gastropod mollusc collected off the Gulf of Mannar on the south-eastern coast of India was studied for the nutritional composition. The edible portion of C. ramosus demonstrated protein content with balanced ratio of essential to non-essential amino acids $(\sim 0.94)$. The $\mathrm{C}_{20}-\mathrm{C}_{22} n-3$ fatty acids, eicosapentaenoic acid and docosahexaenoic acid, were predominant in the edible part (15.8 and 17.2\% total fatty acids,

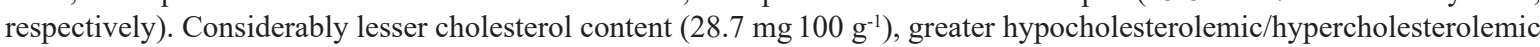
index (6.3) and lesser atherogenic (0.2), thrombogenicity (0.1) indices showed its importance as a cardioprotective and antithrombogenic diet. The presence of antioxidative microelement selenium $\left(30.44 \mu \mathrm{g} 100 \mathrm{~g} \mathrm{~g}^{-1}\right)$ along with ascorbic acid and tocopherol (45.5 and $55.8 \mu \mathrm{g} 100 \mathrm{~g} \mathrm{~g}^{-1}$, respectively) demonstrated the value of this foodstuff to impart antioxidative defense in the metabolic system. A lesser sodium/potassium $(\mathrm{Na} / \mathrm{K})$ proportion $(0.64)$ in C. ramosus could be coupled with a diminished threat of developing hypertension and cardiovascular disease. The aggregate amount of calcium and phosphorus (136.1 mg $100 \mathrm{~g}^{-1}$ ) showed the beneficial effect of this species in facilitating the recruitment of osteoblasts and bone mineralisation process. The previously undescribed report with regard to nutritional composition of C. ramosus appropriately demonstrated this low-value gastropod species as a valuable depot of essential nutritional elements and as a health food for human consumption.
\end{abstract}

Keywords: Chicoreus ramosus, $\mathrm{C}_{20}-\mathrm{C}_{22} n-3$ fatty acids, Hypocholesterolemic/hypercholesterolemic ratio, Marine gastropod mollusc, Thrombogenicity index

\section{Introduction}

New nutritional resources from the oceans are being explored and exploited to meet the nutritional challenge of the increasing world populace. Gastropods have assumed commercial importance as a nutritional resource by virtue of their high quality meat and vast demand in the regional and international markets, particularly in the Mediterranean and Asian countries (Mason et al., 2014). In India, gastropods which were considered as bycatch or was discarded earlier, now forms exclusive gastropod fishery. Muricid gastropods (Family:Muricidae) are gaining therapeutic acceptance as there is much potential to derive high value compounds with pharmacological significance (Naegel and Cooksey, 2002). Chicoreus ramosus (Linnaeus, 1758) commonly known as ramose murex or branched murex, is a species of marine gastropod mollusc in the family Muricidae, which forms a major fishery along the coast of Gulf of Mannar and Palk Bay. However, a detailed nutritional profiling of this muricid gastropod species is still nonexistent. Although a preliminary attempt has been done (Ramesh and Ayyakkannu, 1992), the study was limited to the proximate composition analysis without detailing the quality of the lipid, protein and mineral content in the candidate species. The present work is thus a pioneering study on $C$. ramosus encompassing various nutritional parameters and health indices to examine the nutritional attributes of the edible parts of the species.

\section{Materials and methods}

Samples and study area

Samples of C. ramosus ( $8 \mathrm{~kg}$ ) comprising of mature animals were collected from the fishing harbours of Thoothukudi situated along the Gulf of Mannar region which is located amidst India and Sri Lanka ( $8^{\circ} 48^{\prime} 0 \mathrm{~N}$; $78^{\circ} 09^{\prime} 0$ E) (Fig. 1). The shells were appropriately broken to remove soft body tissues (edible parts) and washed with tap water to remove debris. The tissues were macerated and kept at $-80^{\circ} \mathrm{C}$ for further analysis. 

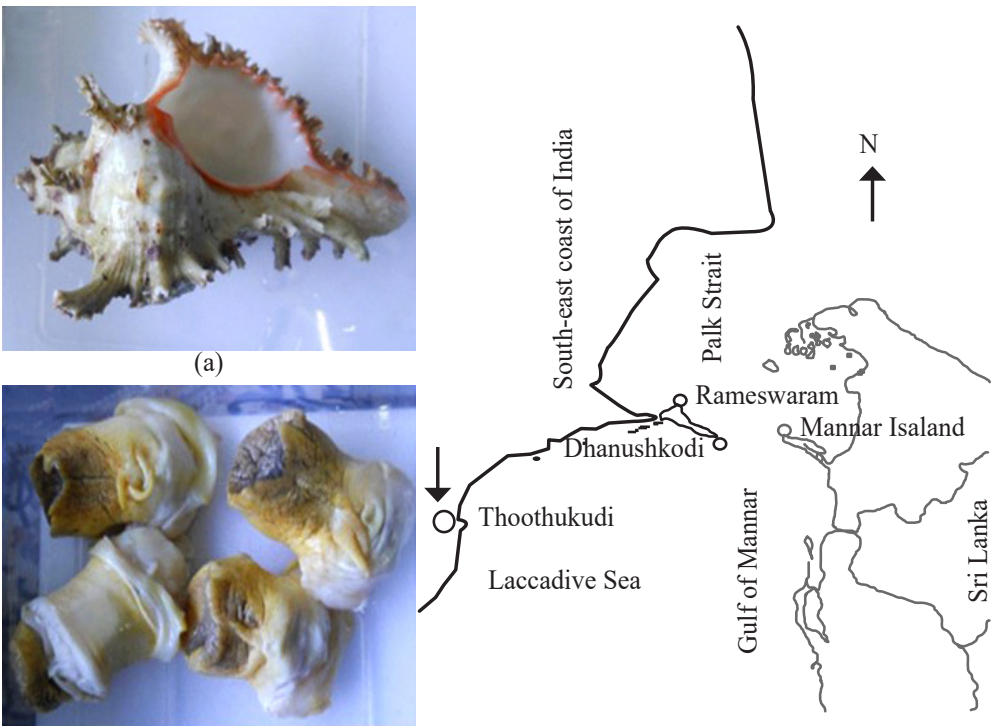

(b)

(c)

Fig. 1 Chicoreus ramous collected from the Gulf of Mannar region. (a) Representative photographs of the morphology of C. ramous; (b) Edible portion of C. ramosus; (c) Map showing collection site of C. ramous in the Gulf of Mannar region in south-east coast of India $\left(8^{\circ} 48^{\prime} \mathrm{N} ; 78^{\circ} 09^{\prime} \mathrm{E}\right)$

\section{Analytical methods}

Total protein content in the tissues of $C$. ramosus was analysed following previously described method (Lowry et al., 1951). Amino acid content analysis was performed according to Pico-Tag method with suitable modifications (Heinrikson and Meredith, 1984), using reversed-phase binary gradient HPLC (Waters reversed-phase Pico.Tag amino acid analysis system). Total carbohydrate content was determined by dinitrosalicyclic acid (DNS) method as described earlier (Chakraborty and Joseph, 2015). ExtractionoflipidswasperformedaspertheFolchextraction method (Folch et al., 1957). Aliquots of the extracted lipids were used to synthesise fatty acid methyl esters (FAME) and evaluated using gas liquid chromatography (GLC) after the method reported by Chakraborty and Joseph (2015). The total cholesterol content in the edible portion of $C$. ramosus was determined colourimetrically as described elsewhere (Wanasundara and Shahidi, 1999) after appropriate modification using o-phthalaldehyde (50 mg $100 \mathrm{ml}^{-1}$ in glacial acetic acid) and the absorbance was measured at a wavelength of $550 \mathrm{~nm}$ using UV-visible spectrophotometer (Varian Cary 50). The total cholesterol content was calculated from the standard curve of cholesterol and expressed as mg100 $\mathrm{g}^{-1}$ edible portion. The fat soluble vitamins were estimated by the earlier method of Chakraborty and Joseph (2015). Content of vitamin $\mathrm{C}$ in the tissues of the gastropod was estimated titrimetrically based on the quantitative discolouration of 2, 6-dichlorophenol indophenol (AOAC, 2005). The mineral content in the edible portion of C. ramosus was determined using Inductively Coupled Plasma Atomic Emission Spectrometer (ICP-AES; Thermo Electron IRIS INTREPID II XSP DUO) subsequent to digestion using the di-acid $\left(\mathrm{HNO}_{3} / \mathrm{HClO}_{4}\right)$ with minor modifications (Chakraborty and Joseph, 2015). The minerals were expressed in mg $100 \mathrm{~g}^{-1}$ of edible portion.

\section{Nutritional quality indices}

Nutritional quality of the edible portions of C. ramosus was assessed using various health indices based on fatty acid and amino acid composition of C. ramosus. The health indices such as $\sum n-6 / \sum n-3$ polyunsaturated fatty acids (PUFAs), docosahexaenoic acid (DHA)/eicosapentaenoic acid (EPA) and total polyunsaturated fatty acids/total saturated fatty acid ( $\sum$ PUFA/ $\sum$ SFA) were evaluated to compare with the recommendations of United Kingdom Department of Health (HMSO, 2001). The indices of atherogenicity (AI) and thrombogenicity (TI) were calculated after the methods reported by Ulbricht and Southgate (1991) and Barrento et al. (2010). The hypocholesterolemic/ hypercholesterolemic $(\mathrm{h} / \mathrm{H})$ ratio was determined as suggested by Santos-Silva et al. (2002). The amino acid score for the essential amino acids was determined as recommended by Food and Agriculture Organisation of the United Nations (FAO)/World Health Organisation (WHO) (FAO/WHO/UNU, 2007).

\section{Statistical analyses}

All analyses were carried out in triplicate. The results were expressed as mean values \pm standard deviation. 
Significance level of the mean of all parameters were set at $p=0.05$ and analysed by one-way analysis of variance (ANOVA) with Scheffe's post-hoc analysis. All statistical evaluations were done using the Statistical Program for Social Sciences 13.0 (SPSS Inc, Chicago, USA, ver. 13.0).

\section{Results and discussion}

The increasing demand for gastropods in the international market as an important commercial fishery commodity has occurred only during the recent decades as a recognition to their nutritional qualities. Recently there has been a tremendous increase in the market value of the meat of C. ramosus, and it has evolved as a potential candidate for sea farming (Nasution and Roberts, 2004). However, structured information concerning the nutritional value of this predominantly available muricid gastropod is unprecedented, except for a short report on its proximate analysis (Ramesh and Ayyakkannu, 1992). Taking into account the promising aspect of utilisation of C. ramosus available in the Indian waters, as a plausible health food and the paucity of information in this line, the present study was designed to examine the nutritional composition with respect to vitamins, minerals, amino acids, protein, fatty acid, total carbohydrate and lipids in edible parts of C. ramosus.

The lipid content in the edible portion of C. ramosus was revealed to be considerably lower (0.39 $\mathrm{mg} 100$ $\mathrm{g}^{-1}$ of edible portion, EP w/w) (Table 1) as compared to the lipid contents of other molluscs, such as Mytilus edulis, Perna viridis and Perna canaliculus (Chakraborty et al., 2016) in which the content of total lipid varied from

Table 1. Fatty acid composition, lipid, cholesterol, total carbohydrate and fatty acid-based nutritional indices of the edible part of C. ramosus collected from the south-west coast of India

\begin{tabular}{|c|c|c|c|}
\hline \multicolumn{4}{|c|}{ Fatty acids ( $\%$ total fatty acids) } \\
\hline \multicolumn{2}{|l|}{ Saturated fatty acids } & \multicolumn{2}{|l|}{ Polyunsaturated fatty acids } \\
\hline $12: 0$ & $0.15^{\mathrm{e}} \pm 0.01$ & $16: 2 n-4$ & $0.86^{\mathrm{e}} \pm 0.03$ \\
\hline $14: 0$ & $0.22^{\mathrm{e}} \pm 0.01$ & $16: 3 n-4$ & $0.18^{\mathrm{e}} \pm 0.02$ \\
\hline $15: 0$ & $3.11^{\mathrm{c}} \pm 0.10$ & $18: 2 n-6$ & $3.56^{\mathrm{c}} \pm 0.01$ \\
\hline $16: 0$ & $6.21^{b} \pm 0.50$ & $18: 3 n-6$ & $3.26^{\mathrm{c}} \pm 0.01$ \\
\hline $17: 0$ & $0.30^{\mathrm{e}} \pm 0.00$ & $18: 3 n-3$ & $0.30^{\mathrm{e}} \pm 0.01$ \\
\hline $18: 0$ & $6.88^{\mathrm{b}} \pm 0.40$ & $20: 2 n-6$ & $2.52^{\mathrm{c}} \pm 0.05$ \\
\hline $20: 0$ & $4.08^{c} \pm 0.20$ & $20: 3 n-6$ & $4.70^{\mathrm{c}} \pm 0.01$ \\
\hline $22: 0$ & $7.16^{\mathrm{b}} \pm 0.50$ & $20: 4 n-6$ & $0.75^{\mathrm{e}} \pm 0.01$ \\
\hline $24: 0$ & $1.04 \mathrm{~d} \pm 0.01$ & $20: 5 n-3$ & $15.83^{\mathrm{a}} \pm 0.03$ \\
\hline \multirow[t]{3}{*}{${ }^{x} \sum$ SFA } & 29.14 & $22: 5 n-3$ & $0.63^{\mathrm{e}} \pm 0.02$ \\
\hline & & $22: 6 n-3$ & $17.17^{\mathrm{a}} \pm 0.05$ \\
\hline & & ${ }^{z} \sum$ PUFA & 49.77 \\
\hline \multicolumn{4}{|c|}{ Monounsaturated fatty acids } \\
\hline $14: 1 n-7$ & $0.11^{\mathrm{e}} \pm 0.01$ & & \\
\hline $15: 1 n-7$ & $1.49^{\mathrm{d}} \pm 0.05$ & $\sum n-3$ & 33.93 \\
\hline $16: 1 n-7$ & $7.01^{\mathrm{b}} \pm 0.20$ & $\sum n-6$ & 14.52 \\
\hline $18: 1 n-7$ & $0.91^{\mathrm{e}} \pm 0.01$ & $\sum n-3 / \sum n-6$ & 2.33 \\
\hline $18: 1 n-9$ & $2.35^{\mathrm{c}} \pm 0.01$ & $\Sigma \mathrm{C} 18$ fatty acids & 7.12 \\
\hline $20: 1 n-9$ & $3.06^{\mathrm{c}} \pm 0.20$ & $\mathrm{DHA}+\mathrm{EPA}$ & 33.00 \\
\hline $22: 1 n-9$ & $6.00^{\mathrm{b}} \pm 0.02$ & $\mathrm{EPA} / \mathrm{AA}$ & 21.11 \\
\hline $24: 1 n-9$ & $0.02^{\mathrm{f}} \pm 0.00$ & DHA/EPA & 1.12 \\
\hline${ }^{\mathrm{y}} \sum \mathrm{MUFA}$ & 20.94 & $\sum \mathrm{PUFA} / \sum \mathrm{SFA}$ & 1.67 \\
\hline \multicolumn{2}{|c|}{ Fatty acid-based nutritional indices } & \multicolumn{2}{|l|}{ Other nutritional parameters } \\
\hline Atherogenicity index & $0.20 \pm 0.01$ & Lipid (\%) & $0.39 \pm 0.02$ \\
\hline Thrombogenicity index & $0.11 \pm 0.01$ & Cholesterol (mg $\left.100 \mathrm{~g}^{-1} \mathrm{EP}\right)$ & $28.7 \pm 1.05$ \\
\hline $\mathrm{h} / \mathrm{H}$ ratio & $6.31 \pm 0.01$ & Carbohydrate (mg $\left.100 \mathrm{~g}^{-1} \mathrm{EP}\right)$ & $5.86 \pm 0.50$ \\
\hline
\end{tabular}

All samples were analysed in triplicate $(n=3)$ from pooled sub-samples, and expressed as Mean \pm SD. Means followed by different superscripts within the same column $(\mathrm{a}-\mathrm{f})$ indicate significant difference $(\mathrm{p}<0.05)$. ND: non detectable x $\mathrm{SFA}$ : Total saturated fatty acids

${ }^{y} \sum$ MUFA: Total monounsaturated fatty acids

${ }^{z} \sum$ PUFA: Total polyunsaturated fatty acids 
1.06-2.50 mg $100 \mathrm{~g}^{-1}$ EP (wet weight). Ramesh and Ayyakkannu (1992) reported the crude lipid content in the edible part of C. ramosus as $2 \mathrm{mg} 100 \mathrm{~g}^{-1}$. Notably, the previous report recorded crude lipid, which apparently included the non-polar to medium polar compounds, such as terpenoids, steroids, anthocyanidins, other than triglyceride and phosphlipidic components. The lipidic variations could be also due to the period of lipid catabolism that influences the lipid utilisation and storage. This present study recorded the total triglyceride content, which has been considered as nutritionally significant component. The study by Ramesh and Ayyakkannu (1992) did not elucidate the finer components of triglycerides, such as fatty acid composition. However, to establish the high nutritional value of the gastropod's lipid content, we determined the individual fatty acid components of the triglyceride fraction, indicating significantly greater share of PUFAs (48.7\% total fatty acids, TFA) among other fatty acid components. Each of the SFAs and MUFAs constituted $<30 \%$ of the total fatty acids in the edible part of the species studied (Table 1). The PUFAs in the edible portion of $C$. ramosus were mainly composed of $n-3$ fatty acids ( $\sim 34 \%$ TFA) than $n-6$ fatty acids $(\sim 15 \%$ TFA $)$. The quality of the lipids in the edible part of C. ramosus were judged by the fatty acid indices, such as $\sum n-3 / \sum n-6$ fatty acid ratio that was deduced to be greater than 2, which has been well above the required threshold, and was significantly greater than various marine and freshwater fish species. A greater proportion of $\sum n-3 / \sum n-6$ fatty acid ratio is proportional to the lipid quality. Diets containing greater $n$-3 PUFA were reported to reduce the plasma concentration of triglycerides and insulin and have been potent inhibitors of inflammatory mediators (Gilroy et al., 2004). The long chain $\mathrm{C}_{20}-\mathrm{C}_{22}$ fatty acids, such as EPA and DHA contributed major shares (43.65 and 50.60\%, respectively) to the $n-3$ PUFAs. The aggregate content of EPA and DHA in the edible portion of C. ramosus $(\sim 33 \%)$ was found to be considerably higher as compared to those found in other species of marine fish and molluscs (Chakraborty et al., 2016). Greater EPA and DHA content in $C$. ramosus are of immense importance due to their contribution in the prevention and therapy of cardiovascular diseases (Dal Bosco et al., 2012). The proportion of these long chain $\mathrm{C}_{20}-\mathrm{C}_{22} n-3$ fatty acids (DHA and EPA) was also found to be closer to 1 , which is significant to meet the requirement of balanced fatty acid nutrition.

The greater content of $n-3$ fatty acids and accordingly greater proportion of $n-3 / n-6$ fatty acids $(\sim 2.3)$ in C. ramosus evidently contributed to the lower values of the AI and TI, which suggested that this foodstuff has been useful in a cardio-protective and anti-thrombogenic diet (Ulbricht and Southgate, 1991). The hypocholesterolemic/ hypercholesterolemic $(\mathrm{h} / \mathrm{H})$ ratio is a significant index as it considers the consequence of fatty acids on the metabolism of cholesterol and a greater value for this ratio are desirable from a nutritional view point. A greater $\mathrm{h} / \mathrm{H}$ ratio recorded in C. ramosus (greater than 6), appeared to contribute towards its preferred nutritional and health qualities.

The results of the protein content (Table 2) in this gastropod species $\left(12.89 \mathrm{mg} \mathrm{g}^{-1}\right)$ was in conformity with the previous studies on freshwater molluscs viz., Melania tuberculata (12.36 $\mathrm{mg} \mathrm{g}^{-1}$ ) and Anisus convexiusculus $\left(12.93 \mathrm{mg} \mathrm{g}^{-1}\right)$ and greater than that obtained for Bellamya bengalensis $\left(8.97 \mathrm{mg} \mathrm{g}^{-1}\right)$ and Lamellidens marginalis (6.46 $\mathrm{mg} \mathrm{g}^{-1}$ ) as reported by Baby et al. (2010). The biological requirement is for amino acids, though the allowances are expressed as protein. Hence we have focused our study on the quality of protein by evaluating the amino acid indices. The amino acid profile of C. ramosus showed that the essential amino acids (EAA) were notably greater in concentrations, when compared to finfishes and other molluscs (Kim and Lall, 2000; Chakraborty and Joseph, 2015), which implied that the proteins in C. ramosus had a greater biological value. The EAA dominated the protein content in $C$. ramosus

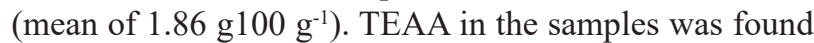
to be close to $50 \%$, well above the adequate limits of $11 \%$ for ideal protein food for adults, $26 \%$ for children and $39 \%$ for infants (FAO/WHO/UNU, 1985; FAO/ WHO, 1990). The TEAA/TAA percentage contents in C. ramosus was found to be closely related to that in egg $(50 \%)(\mathrm{FAO} / \mathrm{WHO}, 1990)$. The EAA/NEAA ratio, of 0.94 recorded in the edible part of $C$. ramosus, indicated that $C$. ramosus could provide high quality proteins or well balanced protein deposition. One of the predominant EAAs in C. ramosus was found to be lysine $(0.26 \mathrm{~g} 100$ $\left.\mathrm{g}^{-1}\right)$ and therefore, could serve as an effective alternative to the plant proteins, which are deficient in lysine content. The leucine/isoleucine ratio $(>1)$ of the edible part of C. ramosus was found to be close to the optimal ratio laid down by FAO/WHO (1990). Lysine content in the edible portion of $C$. ramosus was comparable with that

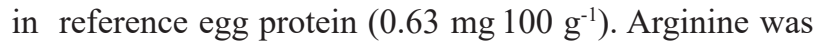
found to be present in an appreciable quantity $(0.55 \mathrm{~g}$ $100 \mathrm{~g}^{-1}$ ) in the edible part of C. ramosus and was found to involve in metabolic processes and important in the treatment of cardiovascular disorders. Notably, lysine is involved in the growth and maintenance of positive nitrogen balance and also used in protein cross-linking, especially collagen. Comparison between the amino acid composition of the present study and the FAO/WHO (1990) reference pattern showed that all the amino acids met the recommended range of amino acid requirements for adults. Since the accepted average daily requirement for 
Table 2. Protein, amino acid, vitamins and mineral composition ( $\mathrm{mg} 100 \mathrm{~g}^{-1}$ edible portion) including essential amino acid score of C. ramosus

\begin{tabular}{|c|c|c|c|}
\hline \multicolumn{2}{|c|}{ Essential amino acids } & \multicolumn{2}{|c|}{ Essential amino acid score } \\
\hline His & $69.30 \pm 0.45$ & His & $282.97^{\mathrm{c}}$ \\
\hline $\operatorname{Arg}$ & $551.3^{\mathrm{a}} \pm 0.50$ & Thr & $425.19^{\mathrm{a}}$ \\
\hline Thr & $186.3^{\mathrm{b}} \pm 1.10$ & Val & $250.34^{c}$ \\
\hline Val & $112.9^{c} \pm 1.04$ & Met+Cys & $384.58^{b}$ \\
\hline Met & $106.2^{c} \pm 0.51$ & Ile & $360.27^{b}$ \\
\hline Ile & $130.0^{c} \pm 0.91$ & Leu & $378.09^{\mathrm{b}}$ \\
\hline Leu & $321.6^{\mathrm{b}} \pm 1.13$ & Phe+Tyr & $245.66^{c}$ \\
\hline Phe & $117.3^{\mathrm{c}} \pm 1.21$ & Lys & $351.84^{\mathrm{b}}$ \\
\hline Lys & $263.0^{\mathrm{b}} \pm 1.45$ & Macrominerals & \\
\hline$\Sigma \mathrm{EAA}$ & $1857.9 \pm 2.10$ & $\overline{\mathrm{Ca}}$ & $38.10^{c} \pm 0.50$ \\
\hline \multicolumn{2}{|c|}{ Non-essential amino acids } & $\mathrm{P}$ & $98.00^{\mathrm{b}} \pm 1.50$ \\
\hline Asp & $418.8^{\mathrm{a}} \pm 1.15$ & $\mathrm{Na}$ & $95.00^{\mathrm{b}} \pm 0.60$ \\
\hline Glu & $701.5^{\mathrm{a}} \pm 1.45$ & $\mathrm{Mg}$ & $75.79^{b} \pm 0.20$ \\
\hline Ser & $176.6^{\mathrm{b}} \pm 1.60$ & $\mathrm{~K}$ & $149.60^{\mathrm{a}} \pm 0.47$ \\
\hline Gly & $198.0^{\mathrm{b}} \pm 1.20$ & Microminerals & \\
\hline Ala & $246.4^{\mathrm{b}} \pm 2.00$ & $\mathrm{Zn}$ & $1.27^{\mathrm{d}} \pm 0.02$ \\
\hline Pro & $137.4^{\mathrm{c}} \pm 0.50$ & $\mathrm{Cu}$ & $0.16^{\mathrm{e}} \pm 0.01$ \\
\hline Tyr & $82.20^{\mathrm{d}} \pm 0.20$ & $\mathrm{Mn}$ & $0.11^{\mathrm{e}} \pm 0.01$ \\
\hline Cys & $17.70^{\mathrm{e}} \pm 0.20$ & $\mathrm{Fe}$ & $1.65^{\mathrm{d}} \pm 0.01$ \\
\hline$\Sigma \mathrm{NEAA}$ & $1978.6 \pm 2.40$ & $\mathrm{Se}$ & $30.44^{c} \pm 0.05$ \\
\hline \multicolumn{2}{|c|}{ Amino acid-based nutritional indices } & Mo & $0.07^{\mathrm{e}} \pm 0.05$ \\
\hline$\sum \mathrm{AA}$ & 3836.5 & Mineral indices & \\
\hline$\sum \mathrm{EAA} / \sum \mathrm{AA}$ & 0.48 & $\overline{\mathrm{Na} / \mathrm{K}}$ & 0.64 \\
\hline$\sum \mathrm{NEAA} / \sum \mathrm{AA}$ & 0.52 & $\mathrm{Ca}+\mathrm{P}$ & 136.1 \\
\hline$\sum \mathrm{EAA} / \sum \mathrm{NEAA}$ & 0.94 & Vitamins & \\
\hline$\sum \mathrm{ArAA}$ & 268.80 & Retinol (A) & $21.89^{\mathrm{b}} \pm 0.01$ \\
\hline$\sum \mathrm{SCAA}$ & 123.90 & Cholecalciferol $\left(\mathrm{D}_{3}\right)$ & $1.21^{\mathrm{c}} \pm 0.02$ \\
\hline Arg/Lys & 2.10 & $\alpha$-tocopherol (E) & $55.82^{\mathrm{a}} \pm 0.90$ \\
\hline Leu/Ile & 2.47 & Phylloquinone $\left(\mathrm{K}_{1}\right)$ & ND \\
\hline Protein $\left(\mathrm{mg} \mathrm{g}^{-1}\right)$ & $12.89 \pm 0.50$ & Ascorbic acid (C) & $45.45^{\mathrm{a}} \pm 0.50$ \\
\hline
\end{tabular}

Data expressed as Mean \pm SD $(n=3)$. The means followed by the same superscript within the same column are not significantly different $(p<0.05)$ and differently shown superscripts in the same row are significantly different $(\mathrm{p}<0.05)$. ND: non detectable

$\sum$ EAA: Total essential amino acids; $\sum$ NEAA: Total non-essential amino acids; $\sum$ AA: Total amino acids; $\sum$ ArAA: Total aromatic amino acids; $\sum$ SAA:

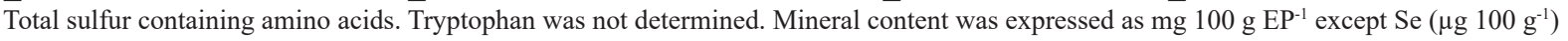

Vitamins were expressed in $\mu \mathrm{g} 100 \mathrm{~g}^{-1}$

reference proteins was found to be $0.6 \mathrm{~g} \mathrm{~kg}^{-1}$ per day (NRC, 1989), C. ramosus could be considered as a complementary protein source. Thus, on the basis of the non-truncated values of the amino acid scores, the proteins in C. ramosus could be recognised as rich source of indispensable amino acids which could be used to supplement the inadequate amino acids in the cereals and other food sources.

Vitamin E along with ascorbic acid contents were significantly greater $(p<0.05)$ in the edible part of C. ramosus (45.5 and $55.8 \mu \mathrm{g} 100 \mathrm{~g}^{-1}$ edible portion, EP) and was found to be more remarkable than that in other shellfish species (Gopalakrishnan and Vijayavel, 2009). The vitamin $\mathrm{A}$ and $\mathrm{D}_{3}$ were present in appreciably greater quantities than those found in the dried tissue sample of the clam Meretrix casta (Srilatha et al., 2013). A greater content of vitamin $\mathrm{D}_{3}\left(1.2 \mu \mathrm{g} 100 \mathrm{~g}^{-1}\right)$ in addition to significant amount of $\mathrm{Ca}\left(38 \mathrm{mg} 100 \mathrm{~g}^{-1}\right)$ and $\mathrm{P}\left(98 \mathrm{mg} 100 \mathrm{~g}^{-1}\right)$ in C. ramosus (Table 2) established its significance in preventing osteoporosis in adults. Presence of greater quantity of antioxidative microelement selenium $\left(30.44 \mu \mathrm{g} 100 \mathrm{~g} \mathrm{~g}^{-1}\right)$ along with ascorbic acid and tocopherol (45.5 and $55.8 \mu \mathrm{g}$ $\left.100 \mathrm{~g}^{-1}\right)$ demonstrated this species as a high value food item to impart antioxidative defense in the metabolic system. The content of total calcium and phosphorus $(136.1 \mathrm{mg}$ $100 \mathrm{~g}^{-1}$ ) in the tissues of C. ramosus echoed the beneficial effect of this species in facilitating the recruitments of osteoblasts and bone mineralisation process. The $\mathrm{Ca} / \mathrm{P}$ ratio was recorded as 0.39 , which reflect that the edible 
part of C. ramosus is of good quality (Erkan and Ozden, 2007). The most abundant microelement in the edible portion of $C$. ramosus was found to be $\mathrm{Fe}(1.65 \mathrm{mg}$ $\left.100 \mathrm{~g}^{-1} \mathrm{EP}\right)$ followed by $\mathrm{Zn}\left(1.27 \mathrm{mg} 100 \mathrm{~g}^{-1} \mathrm{EP}\right)$. The level of $\mathrm{Zn}$ estimated in this study was within the range of fish and seafood reported by FAO (FAO/INFOODS, 2013) The Se content in $C$. ramosus were recorded as $30.44 \mu \mathrm{g}$ $100 \mathrm{~g}^{-1}$ which was significantly greater as compared to those reported in various marine finfishes (10-20 $\mu \mathrm{g}$ $100 \mathrm{~g}^{-1}$ ) (Chakraborty and Joseph, 2015). Increased dietary intake of Se has been associated with the augmentation of antioxidant defense which can counter cellular damage from free radicals and reactive oxygen species (Stephen et al., 2010).

In aquatic molluscs, cholesterol is a prominent sterol having an integral role as secondary messengers in cell signaling and as biosynthetic precursors to vitamins and steroidal hormones. The total cholesterol content in C. ramosus was recorded as $28.7 \mathrm{mg} 100 \mathrm{~g}^{-1} \mathrm{EP}$, which showed lower values as compared to various marine finfish and molluscs (Stephen et al., 2010; Chakraborty and Joseph, 2015). Interestingly, the edible portion of C. ramosus recorded significantly lower total cholesterol content than those of beef, pork, poultry and processed meat products (Dinh et al., 2011). These findings demonstrated $C$. ramosus as a preferred food from human health perspective.

The carbohydrate content in C. ramosus was found

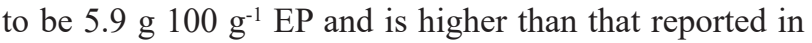
marine neogastropod $C$. melo, which ranged from 2.59 to $5.14 \%$ (Palpandi et al., 2010). Further, high carbohydrate content of $16 \%$ was recorded in $C$. ramosus by Ramesh and Ayyakkannu (1992). The carbohydrate content in molluscs has been primarily composed of glycogen and the carbohydrate reserves might fluctuate due to accumulation and usage of glycogen at various stages like gametogenesis and spawning (Ansari et al., 1981).

The present study is the first report to demonstrate this low-value species (C. ramosus) as an important source of key nutritional elements essential for the human nutrition and metabolic pool. This marine gastropod species was found to be rich store house of protein with a notable content of essential/non-essential amino acid ratio. More prominent levels of $\mathrm{C}_{20-22}$ long chain $n-3$ polyunsaturated fatty acids, for example, eicosapentaenoic acids, docosahexaenoic acid and greater fraction of $n-3 / n-6$ fatty acids (2.33), demonstrated that it is good source of wellbalanced diets. The ideal atherogenicity/thrombogenicity indices $(\leq 1.0)$, hypocholesterolemic/hypercholesterolemic ratio and fatty acid/amino acid based health markers in the edible portions qualify this species as a potential health food. The species was also ascertained to be valuable source of several micro and macro minerals and vitamins, which are vital for the metabolic functioning of the body. C. ramosus exhibited a lesser $\mathrm{Na} / \mathrm{K}$ ratio with greater contents of $\mathrm{Ca}, \mathrm{P}$ and antioxidative mineral $\mathrm{Se}$ and could be considered as an important functional food supplement. C. ramosus could be considered as a new source of important health food and could potentially be used in formulating various functional food ingredients for pharmaceutical industries.

\section{Acknowledgements}

This work was funded by the Indian Council of Agricultural Research (ICAR), New Delhi, under the Fisheries Science Division Outreach Activity on Nutrient Profiling and Evaluating Fish as a Dietary Component (ICAR-FSD-OA\#3). We thank the Director, ICAR-Central Marine Fisheries Research Institute for providing the necessary facilities and support. The first author acknowledges the Department of Science and Technology, New Delhi, Govt. of India, for the award of a scholarship.

\section{References}

Ansari, A., Parulekar, A. H. and Motondkar, S. G. D. 1981 Seasonal changes in meat weight and biochemical composition in the black clam, Villorita cyprinoides (Grey). Indian J. Mar. Sci., 10: 128-137.

AOAC 2005. Official methods of analysis, Association of Official Analytical Chemists International. In: Latimer, G. W. and Horwitz, W. (Eds), Association of Analytical Communities, Gaithersburg MD, p. 215-238.

Baby, R. L., Hasan, I., Kabir, K. A. and Naser, M. N. 2010. Nutrient analysis of some commercially important molluscs of Bangladesh. J. Sci. Res., 2: 390-396. DOI: 10.3329/jsr. $\mathrm{v} 2 \mathrm{i} 2.3362$.

Barrento, S., Marques, A., Teixeira, B., Mendes, R., Bandarra, N., Vaz-Pires, P. and Nunes, M. L. 2010. Chemical composition, cholesterol, fatty acid and amino acid in two populations of brown crab Cancer pagurus: ecological and human health implications. J. Food Compost. Anal., 23: 716-725.

Chakraborty, K. and Joseph, D. 2015. Inter-annual and seasonal dynamics of amino acid, mineral and vitamin composition of silver belly Leiognathus splendens. J. Mar. Biol. Assoc. U. K., 95: 817-828. doi.org/10.1017/S0025315414001155.

Chakraborty, K., Chakkalakal, S. J., Joseph, D., Asokan, P. K. and Vijayan, K. K. 2016. Nutritional and antioxidative attributes of green mussel (Perna viridis L.) from the southwestern coast of India. J. Aquat. Food Prod. Technol., 24: 115-124. doi.org/10.1080/10498850.2015.1004498.

Dal Bosco, A., Mugnai, C., Mourvaki, E. and Castellini, C. 2012. Seasonal changes in the fillet fatty acid profile and nutritional characteristics of wild Trasimeno Lake goldfish 
(Carassius auratus L.) Food Chem., 132: 830-834. DOI: 10.1016/j.foodchem.2011.11.043.

Dinh, T. T. N., Thompson, L. D., Galyean, M. L., Brooks, J. C., Patterson, K. Y. and Boylan L. M. 2011. Cholesterol content and methods for cholesterol determination in meat and poultry. Compr. Rev. Food Sci. Food Saf., 10: 269-289. doi.org/10.1111/j.1541-4337.2011.00158.x.

Erkan, N. and Ozden, O. 2007. Proximate composition and mineral contents in aquacultured seabass (Dicentrar chuslabrax), sea bream (Sparus aurata) analysed by ICP-MS. Food Chem., 102: 721-725.

FAO/INFOODS 2013. Food composition database for biodiversity. Food and Agriculture Organisation of the United Nations. Rome, Italy.

FAO/WHO 1990. Report of the joint FAO/WHO expert consultation on protein quality evaluation. Food and Agriculture Organisation and World Health Organisation. Bethesda, MD.

FAO/WHO/UNU 1985. Energy and protein requirements. Report of a joint WHO/FAO/UNU expert consultation. World Health Organisation Technical Report Series, 724. World Health Organisation, Geneva.

$\mathrm{FAO} / \mathrm{WHO} / \mathrm{UNU}$ 2007. Protein and amino acid requirements in human nutrition. Report of a joint WHO/FAO/UNU expert consultation. World Health Organisation, Geneva.

Folch, J., Lees, M. and Stanley, G. H. S. 1957. A simple method for the isolation and purification of total lipids from animal tissues. J. Biol. Chem., 226: 497-509.

Gilroy, D. W., Lawrence, T., Perretti, M. and Rossi, A. G. 2004. Inflammatory resolution: new opportunities for drug discovery. Nat. Rev. Drug Discov., 3: 401-416. DOI: $10.1038 / \mathrm{nrd} 1383$

Gopalakrishnan, S. and Vijayavel, K. 2009. Nutritional composition of three estuarine bivalve mussels, Perna viridis, Donax cuneatus and Meretrix meretrix. Int. J. Food Sci. Nutr., 60: 458-463. doi: 10.1080/09637480701830412.

Heinrikson, R. L. and Meredith, S. C. 1984. Amino acid analysis by reverse-phase high-performance liquid chromatography: pre-column derivatisation with phenylisothiocyanate. Anal. Biochem., 136: 65-74.

HMSO 2001. Nutritional aspects of cardiovascular disease. Report on health and social subjects. Department of Health, London.

Kim, J. D. and Lall, S. P. 2000. Amino acid composition of whole body tissue of Atlantic halibut (Hippoglossus hippoglossus), yellow tail flounder (Pleuronectes ferruginea) and Japanese flounder (Paralichthys olivaceus). Aquaculture, 187: 367-373. doi.org/10.1016/S0044-8486(00)00322-7.
Lowry, O. H., Rosebrough, N. J., Farr, A. L. and Randall, R. J. 1951. Protein measurement with the folin phenol reagent. J. Biol. Chem., 193: 265-275.

Mason, S. L., Shi, J., Bekhit, A. E. and Gooneratne, R. 2014. Nutritional and toxicological studies of New Zealand Cookia sulcata. J. Food Composit. Anal., 36: 79-84.

Naegel, C. A. L. and Cooksey, J. C. 2002. Tyrian purple from marine muricids, especially from Plicopurpura pansa (Gould, 1853). J. Shellfish Res., 21: 193-200.

Nasution, S. and Roberts, D. 2004. Laboratory trials on the effects of different diets on growth and survival of the common whelk, Buccinum undatum L.1758, as candidate species for aquaculture. Aquac. Int., 12: 509-521.

NRC 1989. Subcommittee on the $10^{\text {th }}$ edn. of the Recommended Dietary Allowances. National Research Council, Washington (DC), National Academies Press, United States.

Palpandi, C., Vairamani, S. and Shanmugam, A. 2010. Proximate composition and fatty acid profile of different tissues of the marine neogastropod Cymbium melo (Solander, 1786). Indian J. Fish., 57: 35-39.

Ramesh, X. M. and Ayyakkannu, K. 1992. Nutritive value of Chicoreus ramosus. A status report. Second workshop of the tropical marine mollusc programme. Annamalai University. Phuket Mar. Biol. Cent. Spec. Publ., 10: 14.

Santos-Silva, J., Bessa, R. J. B. and Santos-Silva, F. 2002.Effect of genotype feeding system and slaughter weight on the quality of light lambs. Livest Prod Sci., 77: 187-194. doi. org/10.1016/S0301-6226(02)00059-3.

Srilatha, G., Chamundeeswari, K., Ramamoorthy, K., Sankar, G. and Varadharajan, D. 2013. Proximate, amino acid, fatty acid and mineral analysis of clam, Meretrix casta (Chemnitz) from Cuddalore and Parangipettai coast, southeast coast of India. J. Mar. Biol. Oceanogr., 2: 16-28. Doi. org/10.4172/2324-8661.1000111.

Stephen, N. M., Shakila, R. J., Jeyasekaran, G. and Sukumar, D. 2010. Effect of different types of heat processing on chemical changes in tuna. J. Food Sci. Technol., 2: 174-181. doi: [10.1007/s13197-010-0024-2].

Ulbricht, T. L. V. and Southgate, D. A. T. 1991. Coronary heart disease: seven dietary factors. Lancet, 338: 985-992. doi. org/10.1016/0140-6736(91)91846-M.

Wanasundara, U.N. and Shahidi, F. 1999. Concentration of omega 3-polyunsaturated fatty acids of seal blubber oil by urea complexation: optimisation of reaction conditions. Food Chem., 65: 41-49. DOI: 10.1016/S0308-8146(98)00153-8. 